\title{
多角錐台型ピトープローブの高高度における 計測精度向上*1 Measurement Accuracy Improvement of the Pitot Probe with Multi-Hole Pyramidal Head at High Altitude Condition
}

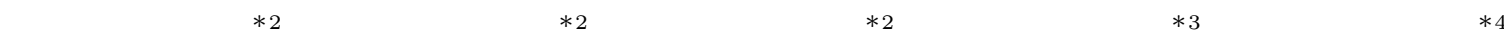 \\ Tomonari Hirotani, Makoto Ueno, Masashi Shigemi, Hiroshi Wakai and Toru Iwata
}

Key Words : Aircraft Instrument, Pitot Tube, Multi-Hole Probe, Velocity Measurement

\begin{abstract}
The Pitot probe with 5-hole pyramidal head originally developed by NAL was planed to be adopted in the early phase of the development of the High-Speed Flight Demonstration Phase II. But it was turned out that the probe could not achieve enough ability of Mach number measurement at high altitude condition. To improve the ability of the ADS, pressure holes were added on the aft surface of the probe. As the result, the error of Mach number measurement due to the errors of pressure sensors became $2.7 \%$ of an original error at best condition, and the new probe could achieve adequate accuracy of Mach number.
\end{abstract}

\section{記 号 の 説 明}

$$
\begin{aligned}
& M: \text { マッハ数 } \\
& P_{\mathrm{t}}: \text { 総圧 } \mathrm{Pa} \\
& P: \text { 静圧 } \mathrm{Pa} \\
& P_{\mathrm{d}}: \text { 動圧 } \mathrm{Pa} \\
& P_{\mathrm{b} 1 \sim 4}: 4 \text { の角錐面の圧力孔計測圧 } \mathrm{Pa} \\
& P_{\mathrm{b}}: P_{\mathrm{b} 1 \sim 4} \text { の平均値 } \mathrm{Pa} \\
& P_{\mathrm{s}}: \text { 静圧孔計測圧 } \mathrm{Pa} \\
& \alpha: \text { 機体の迎角 } \operatorname{deg} \\
& \beta: \text { 機体の横滑り角 } \mathrm{deg} \\
& C_{M}: \text { マッ八数圧力係数 } \\
& C_{\alpha}: \text { 迎角圧力係数 } \\
& C_{\beta}: \text { 横滑り角圧力係数 } \\
& C_{\gamma}: \text { 気流角圧力係数 }\left(=\sqrt{C_{\alpha}{ }^{2}+C_{\beta}{ }^{2}}\right) \\
& \kappa: \text { 空気の比熱比 }(=1.4)
\end{aligned}
$$

\section{1. は じめに}

従来 , 航空機搭載のエア・データ・センサ・システム (以 下, ADS) としては, 球形プローブ，ピラミッド型プロー ブを用いたもの及び通常のピト一管と矢羽根型 $\alpha / \beta$ センサ を用いたもの等か開発されている．しかし，各方式とも弱 点がある . 従来型の総圧孔を用いた多孔型のプローブ等は 大きな姿勢角で飛行する場合, 総圧・静圧検出に誤差を生 じ, エア・データ計測に複雑な補正が必要である。また，矢 羽根型角度センサは飛行中, 矢羽根に振動が起き大きな角

\footnotetext{
*1 (C) 2005 日本航空宇宙学会

平成 16 年 9 月 22 日原稿受理

$* 2$ 宇宙航空研究開発機構

*3 富士重工業 (株)

$* 4$ 東京航空計器 (株)
}

\section{度誤差を生じる場合がある．}

これらの弱点がなく，また，可動部や複雑な補正を必要 とせずにエア・データを計測する技術として，航空宇宙技 術研究所では風洞内後流測定用に開発したキールチューブ 型総圧管方式の多孔プローブに関する特許「多角錐台型ピ ト一管型プローブ」1)をもとに, 東京航空計器 (株) と共同 で実機搭載型プローブ (四角錐台型 5 孔ピトープローブ) の開発を行った 2 (4).

このプローブと専用のエア・データ・コンピュータ（以下， $\mathrm{ADC})$ から構成される ADS は, ハードウェアとしては 1996 年に実験が行われた HOPE 小型着陸実験機 (ALFLEX) ${ }^{5}$ で実用された .弚して, 宇宙往還機形状の遷音速領域におけ る機体の空力特性データを取得することを主目的とした飛 行実験である，高速飛行実証フェーズII ${ }^{6)}$ (以下，HSFD2） においても使用されることが検討され，遷音速領域での較 正風洞試験が行われるなど, 所要の準備が進められていた .

しかし, 準備の過程において, 四角錐台型 5 孔ピトープ ローブを用いた計測では, 高高度の空気の希薄な領域では， マッ八数や静圧の測定において飛行に必要な精度が得られ ないことか明らかになった . 対応策を模索する中で, プロー ブの中胴に新たに静圧孔を設けて , 静圧情報を付加するこ とによりマッハ数を精度良く決定できることか理解され，四 角錐台型 5 孔ピトープローブ (以下,「旧プローブ」) に静 圧孔を付加した新方式のプロープ7)（以下，「新プローブ」） が開発された .

この新プローブと専用のエア・データ算出モデルを用い た計測では，旧プローブを使用した場合と比較して，高度 $22500 \mathrm{~m}$, 高度 $18000 \mathrm{~m}$, マッ八数 $0.2 \sim 1.4$ の条件下では, 圧力センサ誤差に起因するマッハ数の計測誤差が平均で約 $1 / 3(34.9 \%)$ に低下し, 特に高度 $18000 \mathrm{~m}$, マッ八数 1.0 では約 $1 / 40(2.7 \%)$ に低下した .これにより飛行試験の計 
測目的及び飛行制御の成立に必要な計測精度を達成できた。

本稿では，四角錐台型 5 孔ピトープローブを用いた ADS の計測精度が高高度において低下する問題に対して行った 検討，対策について述べ，兴の結果として製作された新方 式の四角錐型ピトープローブと光れを用いた場合のエア . データ算出モデル, 光れにより得られた計測精度について 述べる。

\section{2. 四角錐台型 5 孔 ADS の問題点}

HSFD2 では当初，四角錐台型 5 孔ピトープローブの搭 載が予定されていた．しかし，検討の過程において，高高度 の空気の希薄な領域では, マッ八数や静圧の測定において 飛行に必要な精度が得られないことが明らかになった .こ こで，四角錐台型 5 孔ピトープローブ (旧プローブ) の概 略と高高度で使用する場合の問題点について述べる。

2.1 四角錐台型 5 孔ピトープローブの概略 第 1 図に 旧プローブの外観図を示す . この図に示すように旧プロー ブは四角錐台頭部をもつ円柱の中心に総圧計測用のキール チューブを配置し，4つの角錐面の各々に圧力孔を設けた 角錐型 5 孔ピト一管型プローブである . 総圧計測用のキー ルチューブは総圧管と乥れを取り巻く遮蔽管の二重管構造 となっており，気流の角度によらず総圧を計測できる．角 錐面の角度はプローブ軸に対して $45 \mathrm{deg}$ である . 各圧力孔 の圧力計測は絶対圧センサにより行われ，これらの圧力情 報が $\mathrm{ADC}$ に取り込まれ，演算処理の後，エア・データと して出力される.

2.2 四角錐台型 $\mathbf{5}$ 孔ピトープローブを用いた計測 以 下に旧プローブを用いた場合の，計測された圧力データか らマッ八数, 機体の迎角, 横滑り角, 静圧, 動圧を算出す るための演算処理モデルを示す．

第 1 図に示す各圧力孔の計測圧を入力とし，次式により 各圧力係数を算出する.

$$
\begin{aligned}
& C_{M}=\left(P_{\mathrm{t}}-P_{\mathrm{b}}\right) / P_{\mathrm{t}} \\
& C_{\alpha}=\left(P_{\mathrm{b} 1}-P_{\mathrm{b} 3}\right) / P_{\mathrm{t}} \\
& C_{\beta}=\left(P_{\mathrm{b} 2}-P_{\mathrm{b} 4}\right) / P_{\mathrm{t}} \\
& C_{\gamma}=\sqrt{C_{\alpha}{ }^{2}+C_{\beta}{ }^{2}}
\end{aligned}
$$

ただし，

$$
P_{\mathrm{b}}=\left(P_{\mathrm{b} 1}+P_{\mathrm{b} 2}+P_{\mathrm{b} 3}+P_{\mathrm{b} 4}\right) / 4
$$

次に較正風洞試験により得られているマッハ数算出データ マップ (第 2 図) より， $C_{M}, C_{\gamma}$ を用いてマッハ数 $M$ を求

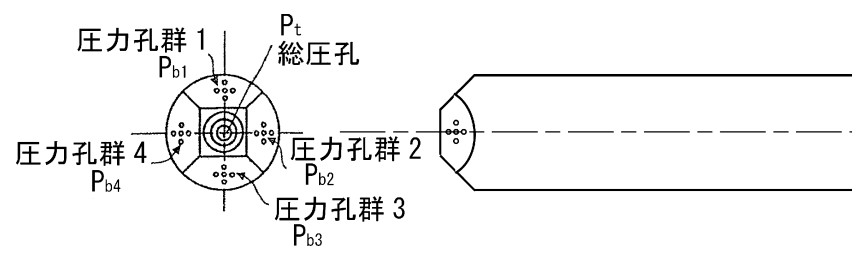

第 1 図 四角錐型 5 孔ピトープローブ (旧プローブ) の外観図
める.機体の迎角 $\alpha$, 横滑り角 $\beta$ は次式により求める. ま た，静圧 $P$, 動圧 $P_{\mathrm{d}}$ はすでに算出されているマッ八数 $M$ 及び総圧 $P_{\mathrm{t}}$ を用いて等エントロピーの関係式から求める.

$$
\begin{aligned}
\alpha= & \left(a_{00}+a_{01} M+a_{02} M^{2}+a_{03} M^{3}+a_{04} M^{4}\right. \\
& \left.+a_{05} M^{5}\right) \\
& +\left(a_{10}+a_{11} M+a_{12} M^{2}+a_{13} M^{3}+a_{14} M^{4}\right. \\
& \left.+a_{15} M^{5}\right) C_{\alpha} \\
& +\left(a_{20}+a_{21} M+a_{22} M^{2}+a_{23} M^{3}+a_{24} M^{4}\right. \\
& \left.+a_{25} M^{5}\right) C_{\alpha}{ }^{2} \\
& +\left(a_{30}+a_{31} M+a_{32} M^{2}+a_{33} M^{3}+a_{34} M^{4}\right. \\
& \left.+a_{35} M^{5}\right) C_{\alpha}{ }^{3} \\
\beta= & \left(b_{00}+b_{01} M+b_{02} M^{2}+b_{03} M^{3}+b_{04} M^{4}\right. \\
& \left.+b_{05} M^{5}\right) \\
& +\left(b_{10}+b_{11} M+b_{12} M^{2}+b_{13} M^{3}+b_{14} M^{4}\right. \\
& \left.+b_{15} M^{5}\right) C_{\beta} \\
& +\left(b_{20}+b_{21} M+b_{22} M^{2}+b_{23} M^{3}+b_{24} M^{4}\right. \\
& \left.+b_{25} M^{5}\right) C_{\beta}{ }^{2} \\
& +\left(b_{30}+b_{31} M+b_{32} M^{2}+b_{33} M^{3}+b_{34} M^{4}\right. \\
& \left.+b_{35} M^{5}\right) C_{\beta}{ }^{3}
\end{aligned}
$$

係数 $a, b$ は較正風洞試験より各マッハ数 $M$ について得ら れている.

これらの演算処理は機体に搭載されている ADCにより 行われ, 演算結果がフライト・コントロール・コンピュー タ（以下，FCC) に送られる。

2.3 高高度における計測誤差シミュレーション HSFD2 の飛行試験環境がこれまでに旧プローブを用いた ADS が 使用された環境と大きく異なる点は, 高高度の空気の薄い 環境であるということである，弚のため，高高度で使用す る場合の誤差シミュレーションを実施した . 高高度環境と

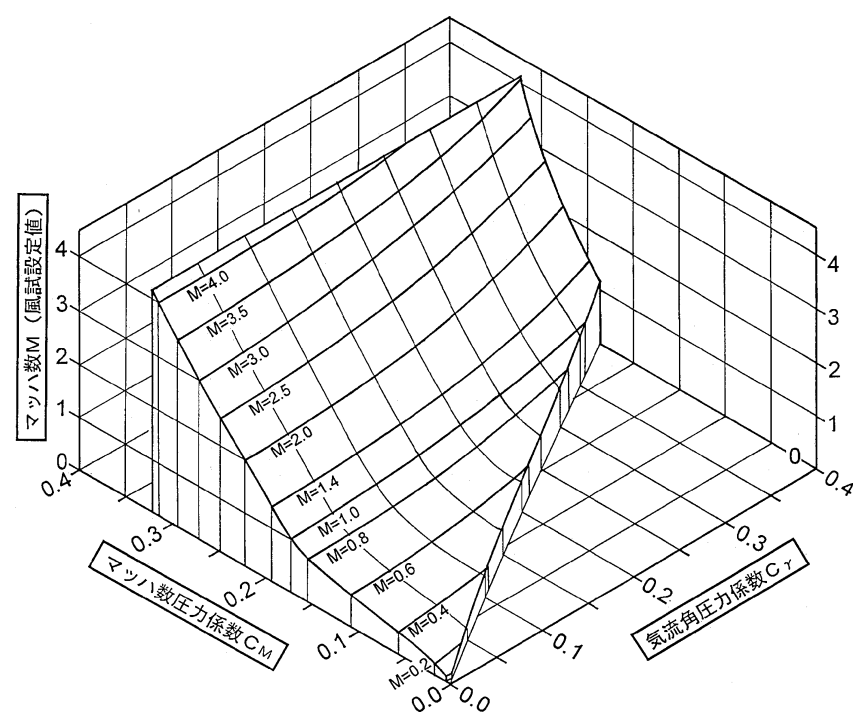

第 2 図 四角錐型 5 孔ピトープローブ用マッ八数算出データマップ 


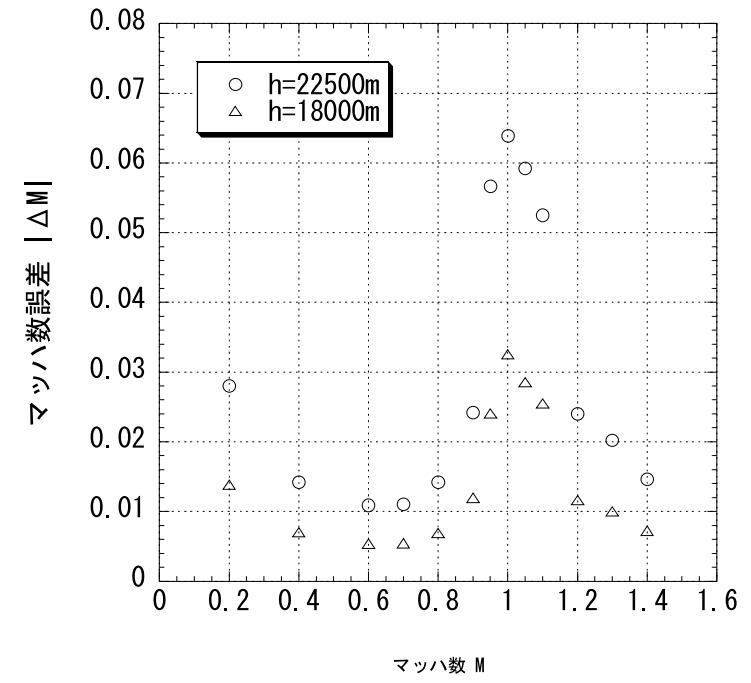

第 3 图 旧プローブを使用した場合の誤差シミュレーション結果

通常の環境で大きく異なる点は各圧力孔で計測される圧力 值の大きさである . 本検討では高度の違いによるエア・デー タの計測精度の変化に注目しているため, 誤差源は絶対圧 センサの計測誤差 (13Pa) のみとした . また , シミュレー ション条件は以下の通りである.

•高度 : $22500 \mathrm{~m}, 18000 \mathrm{~m}$

・マッ八数 : $0.2,0.4,0.6,0.7,0.8,0.9,0.95,1.0,1.05$, $1.1,1.2,1.3,1.4$

·機体迎角 : $0.0 \mathrm{deg}$

・機体横滑り角 : $0.0 \mathrm{deg}$

この結果を第 3 図に示す.これから，マッハ数 0.2 及び遷音 速域においてマッ八数の誤差が大きくなっていることが分 かる.マッハ数 0.2 においてマッ八数の誤差が大きいこと は, この領域が HSFD2 の試験領域ではないため問題とは ならないが, 試験領域である遷音速域においてマッハ数の 誤差が大きいため, マッハ数を用いて算出される静圧, 動 圧等の誤差も増加し，飛行試験の計測目的及び飛行制御の 成立が困難になると考えられた .

\section{3. 精度向上のための方針}

必要な精度の達成が困難である原因として，以下に示す 3 要因が考えられる .

(1) 旧プローブは絶対圧センサを用いる仕樣上，高高度で 空気の薄い領域では計測圧力に対する誤差量が増加する。 つまり，地上付近においても計測可能なフルレンジの一定 割合である誤差量は，高高度での計測圧力に対して比較的 大きい .

(2) 旧プローブでは, マッ八数はピト一管先端の総圧と光 れを取り巻く 4 面の計測圧平均值の差分を用いて算出され るが, 通常のピト一管のようにピト一管並行部の計測圧に よるマッ八数計測に対し, 圧力差が半分以下となるため, 誤 差量の比率が増大する .

(3) マッ八数 1 付近では 5 孔圧からマッハ数を計算する較 正カーブの傾斜が急激に大きくなり，結果として圧力誤差

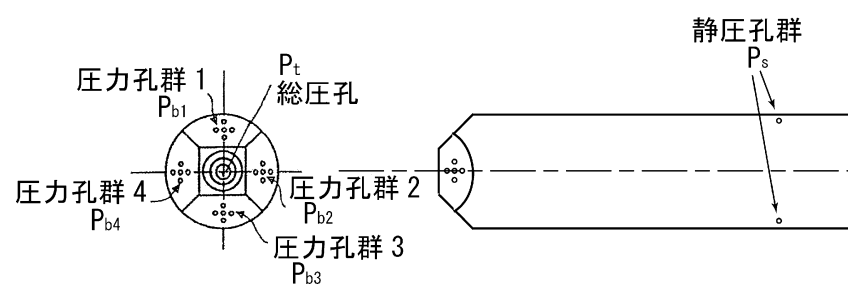

第 4 図 新方式の四角錐型ピトープローブ (新プローブ) の外観図

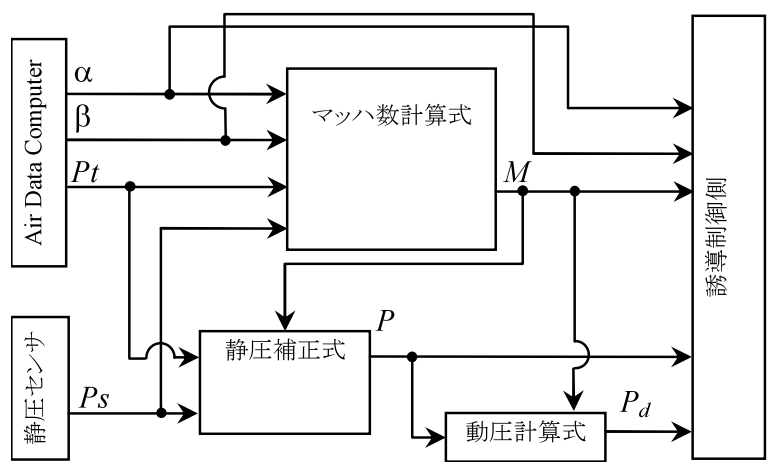

第 5 図＼cjkstart新プローブを使用した ADS のモデル図

に対するマッハ数変化の感度か増加する．

要因(1)関しては, より高精度の絶対圧センサを使用す ることにより改善することができるが , 現状ではさらに高 精度な絶対圧センサを入手することは困難である．また， 要因(3に関しては, 旧プローブの空力特性产のものである ため, 改善することは非常に難しい.よって要因(2)に対し， 精度向上対策を検討した 。

マッ八数の計測誤差が大きいことは (1) 式の $P_{\mathrm{t}}-P_{\mathrm{b}}$ が 小さいことに起因していると考えられるため，これに相当 する量を増加するような対策を施せば，マッハ数の誤差は 低下すると考えられる. ぞのため，第 4 図に示すようにピ 卜一管並行部に静圧孔を追加した新方式の四角錐型ピトー プローブ (新プローブ) を開発した . 各静圧孔はピト一管 内部で接続され，ピト一管並行部の平均圧力か計測されて いる．これにより総圧と比較的差の大きな静圧孔の圧力情 報を用いてマッ八数を算出することが可能になる。ただし， 追加された静圧孔の圧力情報を ADC に組み込むことはコ スト的，スケジュール的に困難であったため，FCC 内にエ ア・データの算出を行う部分を新たに設け, ADC の演算結 果と静圧孔の圧力情報を用いてマッ八数, 静圧, 動圧の算 出を行うこととした .これを模式的に表した図を第 5 図に 示す。

\section{4. 新方式の演算モデル}

以下に FCC 内に新たに設けられたエア・データの演算 処理モデルを示す．機体の迎角 $\alpha$ と横滑り角 $\beta$ については 既存の方式による計測でも，十分な精度が得られることが 分かったため, ADC の演算結果（式 (6)，式 (7)) を谷の まま使用している .

エア・データ算出における入力は ADC により算出された 


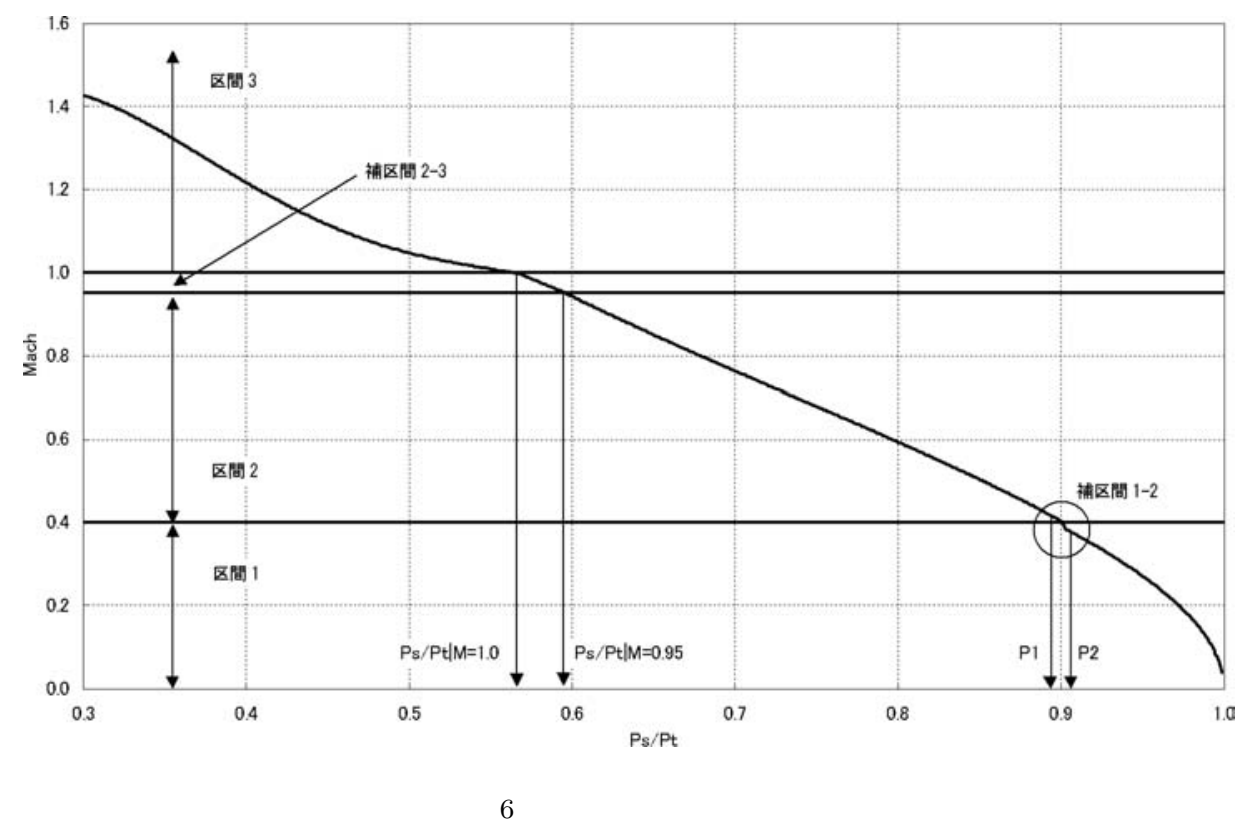

機体の迎角 $\alpha$, 横滑り角 $\beta$, 追加された静圧孔の圧力 $P_{\mathrm{s}}$ 及 び $\mathrm{ADC}$ から光のまま FCC に送られる総圧 $P_{\mathrm{t}}$ の比 $P_{\mathrm{s}} / P_{\mathrm{t}}$ である.マッ八数は $P_{\mathrm{s}} / P_{\mathrm{t}}$ に関して次の 5 区間 (第 6 図) に分けて求める.

(区間 1) $0.91433=P_{2}<P_{\mathrm{s}} / P_{\mathrm{t}}$

(区間 2$) \quad P_{\mathrm{s}} / P_{\mathrm{t} \mid M=0.95}<P_{\mathrm{s}} / P_{\mathrm{t}}<0.89561=P_{1}$

(区間 3) $\quad P_{\mathrm{s}} / P_{\mathrm{t}} \leq P_{\mathrm{s}} / P_{\mathrm{t} \mid M=1.0}$

(補区間 1-2) $\quad P_{1} \leq P_{\mathrm{s}} / P_{\mathrm{t}} \leq P_{2}$

(補区間 2-3) $\quad P_{\mathrm{s}} / P_{\mathrm{t} \mid M=1.0}<P_{\mathrm{s}} / P_{\mathrm{t}} \leq P_{\mathrm{s}} / P_{\mathrm{t} \mid M=0.95}$ マッハ数 0.95 及びマッハ数 1.0 における圧力比 $P_{\mathrm{s}} /$ $P_{\mathrm{t} \mid M=0.95}, P_{\mathrm{s}} / P_{\mathrm{t} \mid M=1.0}$ は各迎角 $\alpha$, 横滑り角 $\beta$ について 較正風洞試験より得られている。

区間 1〜3 においてマッ八数は次式により算出される. (区間 1)

$$
M=\sqrt{2 /(\kappa-1)\left\{\left(P_{\mathrm{s}} / P_{\mathrm{t}}\right)^{(1-\kappa) / \kappa}-1\right\}}
$$

(区間 2) 及び (区間 3)

$$
M=\sum_{i=0}^{4} \sum_{j=0}^{i} c_{(i-j), j} \alpha^{(i-j)}\left(P_{\mathrm{s}} / P_{\mathrm{t}}\right)^{j}
$$

係数 $c$ は各横滑り角 $\beta$ について較正風洞試験より得られて いる。

また，補区間 1-2 及び補区間 2-3では区間の両端の值を 区間 1 3の式 (式 (8), 式 (9)) を用いて算出し, 、間中の 值を区間両端の值を用いて補間により求める . 静圧 $P$, 動 圧 $P_{\mathrm{d}}$ は次式により求める.

$$
\begin{aligned}
& P=P_{\mathrm{s}}\left\{k\left(P_{\mathrm{s}} / P_{\mathrm{t}}\right)+l\right\} \\
& P_{\mathrm{d}}=\kappa / 2 M^{2} P
\end{aligned}
$$

係数 $k, l$ は較正風洞試験により各マッハ数 $M$ について得 られている。

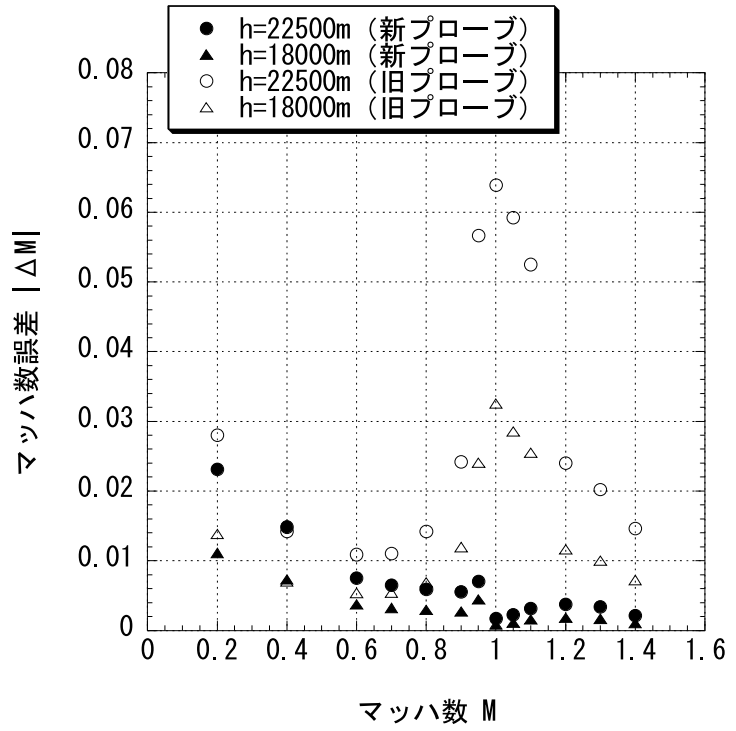

第 7 図 新方式の四角錐台型ピトープローブを使用した場合の誤差シ ミュレーション結果

\section{5. 新 $\mathrm{ADS}$ の誤差シミュレーション}

新プローブによるエア・データの計測についても誤差シ ミュレーションを実施した . 旧プローブを用いた場合につい て行ったシミュレーションと同樣に誤差源は絶対圧センサ の計測誤差のみとし , シミュレーション条件も同じである . このシミュレーション結果及び旧プローブを用いた場合 のシミュレーション結果との比較を第 7 図に示す.この図 からプローブの改良により, 全体的にマッハ数の誤差が低 下していることが分かる.このシミュレーションの条件 , つ まり高度 $22500 \mathrm{~m}$, 高度 $18000 \mathrm{~m}$, マッ八数 $0.2 \sim 1.4$ の条 件下では, マッ八数の計測誤差が平均で $34.9 \%$ に低下して いる．さらに，HSFD2 の飛行試験領域である遷音速域に おいてマッハ数の計測誤差の低下は顕著であり，特に高度 


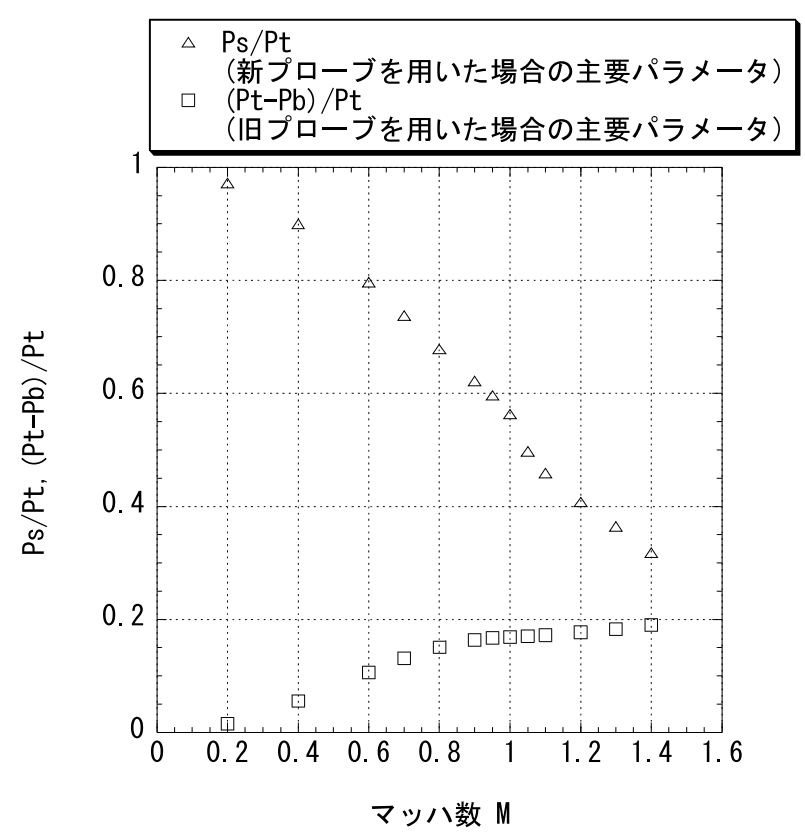

第 8 図 マッハ数算出式の主要パラメータの比較

$18000 \mathrm{~m}$ ，マッ八数 1.0 では $2.7 \%$ に低下した .

マッハ数の計測誤差が低下した要因として，まず，ピトー 管並行部に静圧孔を追加し，比較的総圧との差が大きな静 圧孔の圧力情報を用いてマッハ数を算出したことが考えら れる.第 8 図に示すように，新プローブを用いた場合の マッ八数算出式における主要パラメータ $P_{\mathrm{s}} / P_{\mathrm{t}}$ と旧プロー ブを用いた場合のマッハ数算出式における主要パラメータ $\left(P_{\mathrm{t}}-P_{\mathrm{b}}\right) / P_{\mathrm{t}}$ を比較すると，新プローブを用いた場合のパ ラメータ $P_{\mathrm{s}} / P_{\mathrm{t}}$ の方が大きな值となるため, マッハ数計測 誤差に対する絶対圧センサの誤差の影響が小さいいえる

また，新プローブを用いた場合には，ピト一管並行部に 静圧孔を追加するという機械的な加工による影響以外にも， マッハ数算出式を新たに較正し直したことによる影響も大 きいと考えられる .

マッ八数の計測誤差の原因としては，本稿において検討 した絶対圧センサの誤差以外にもピトープローブの製作誤 差 , 演算処理アルゴリズムのモデル化による誤差等が存在 する．これらの影響を考慮し，さらに絶対圧センサの誤差 による影響もワーストオンワーストのケースでマッハ数の 計測誤差を見積もつた場合でも，飛行試験の計測フェーズ においてマッハ数の計測誤差は 0.03 以下であった .これに より飛行試験の計測目的及び飛行制御の成立に必要な計測 精度を達成できた．なお，飛行後解析においては演算処理 を行う計算機の処理能力が十分に高いため, ピトープロー
ブの各圧力孔の圧力情報を用いて，より高精度なエア・デー タを改めて算出した8).

$$
\text { 6. おわりに }
$$

本稿では, 四角錐台型 5 孔ピトープローブを用いた ADS の計測精度が高高度において低下する問題に対して行った 検討，対策について述へ，关の結果として製作された新方 式の四角錐型ピトープローブと关れを用いた場合のエア . データ算出モデル, 光れにより得られた計測精度について 述べた . 新方式の四角錐型ピトープローブを用いることに より, 高高度においても十分なマッ八数計測精度が得られ， HSFD2 の飛行試験の計測目的及び飛行制御の成立に必要 な計測精度を達成できた . 本検討において得られた知見及 び成果を以下にまとめる .

・多角錐台型ピトープローブを用いた ADS では，総圧と 比較的差の大きなピト一管並行部の静圧情報を用いるこ とにより，高高度における計測精度が向上する。

・上記改良により，本稿において検討した条件下では，圧 カセンサ誤差に起因するマッハ数の計測誤差が平均で $34.9 \%$ に低下した 。

·計測誤差の低下は特に遷音速域において顕著であり，高 度 $18000 \mathrm{~m}$, マッ八数 1.0 の条件では, 圧力センサ誤差 に起因するマッハ数の計測誤差は $2.7 \%$ に低下した .

\section{参 考 文 献}

1) 中谷輝臣, 林 良生 : 特許 : 多角錐台型ピト一管型プローブ, 特 許番号: 第 1454343 号, 1988 .

2) 中谷輝臣, 鈴木誠三, 桑野尚明, 半沢麻雄, 斉藤隆司, 宇佐見光 男, 岩田 徹: 航空機の速度ベクトル計測用ピト一管 (第 1 報), 日本航空宇宙学会第 23 期年会講演集, 1992 .

3) 中谷輝臣, 鈴木誠三, 桑野尚明, 半沢麻雄, 斉藤隆司, 宇佐見光 男, 岩田 徹: 航空機の速度ベクトル計測用ピト一管 (第 2 報), 第 30 回飛行機シンポジウム講演集, 1992.

4) 中谷輝臣, 鈴木誠三, 桑野尚明, 半沢麻雄, 斉藤隆司, 宇佐見光 男, 岩田 徹: 航空機の速度ベクトル計測用ピト一管 (第 3 報), 第 30 回飛行機シンポジウム講演集, 1992.

5) 永安正彦, 中安英彦, 田中敬司, 小野孝次, 谷内 朗 : HOPE 小 型実験機による自動着陸飛行実験 (ALFLEX) について, 日本 航空宇宙学会誌 , 46 (1998), pp. 2-11.

6) Ueno, M., Sarae, W., Tsujimoto, T., Yanagihara, M., Hirotani, T. and Vebel, S.: Aerodynamic Characteristics Estimation of the High Speed Flight Demonstrator Phase II Using Flight Test Data, AIAA Paper 2004-4943, 2004.

7) 重見 仁, 小池 陽, 上野真, 廣谷智成, 中谷輝臣, 若井 洋, 岩田 徹: 特許: 高空用の高速度域飛行速度ベクトル計測システ 厶 (出願中).

8）上野 真, 廣谷智成, 辻本健士 : 飛行実験データによる高速飛行 実証フェーズ II 実証機の空力特性推定，日本航空宇宙学会誌，52 (2004), pp. 335-341. 